\title{
Pathogenesis of Salmonella enterica serovar Albany in experimental infected SPF BALB/c Mice
}

\author{
J.B. Sabri' ${ }^{1}$, I.I. Al-Sultan ${ }^{2}$, K. Altaif ${ }^{3 *}$, S. Peter ${ }^{1}$ and M.J. Saadh ${ }^{3}$ \\ ${ }^{1}$ Department of Paraclinical Studies, Faculty of Veterinary Medicine, University Malaysia Kelantan, Kelantan, ${ }^{2}$ Department of \\ Pathology, Faculty of Medicine, Lincoln University, Malaysia, ${ }^{3}$ Department of Pharmacy, Faculty of Pharmacy, Middle East \\ University, Amman, Jordan, *email: kaltaif@meu.edu.jo
}

(Received November 11, 2020; December 12, 2020; Available online July 12, 2020)

\begin{abstract}
Salmonellosis remains an important zoonotic disease and public health concern, Salmonella enterica serovar Albany is one of the motile serovars which has been identified from poultry and humans. However, its pathogenic potentials and shedding probability and duration from infected/colonized chickens have never been reported. To assess its pathogenic potentials and shedding probability $6 \mathrm{SPF}$ BALB/c mice was inoculated with $0.1 \mathrm{ml}$ volume for each mice bacterial solution of $10^{8} \mathrm{CFU} / \mathrm{ml}$ of Salmonella entrica serovar Albany after 24 hours the segments of the duodenum, jejunum, ileum, caecum and colon were fixed to study the histopathology and the polymerase chain reaction (PCR) was used to confirm the Salmonella entrica serovar Albany in the intestinal mucus swabs. The control group consist of 6 SPF BALB/c mice were inoculated with $0.1 \mathrm{ml}$ of $0.9 \%$ normal saline, The pathogenesis incidence rate of the disease caused by S. entrica serovar Albany revealed that prominent blood vessels on caecum $100 \%$, red intestinal serosal $100 \%$, infiltration of inflammatory cells in the crypt of liberkhun and submuscular layer of small intestine $100 \%$, enterocyte necrosis $100 \%$, haemorrhagic enteritis $83.3 \%$, cecitis $33.3 \%$, colonitis $66.6 \%$, villus atrophy $100 \%$, crypt atrophy $100 \%$, and detachment of epithelial tissue $50 \%$, can occur as soon as 24 hours post infection. Infected S. entrica serovar Albany was also successfully re-isolated from the intestinal swabs which revealed that the mice is potentially shed the bacteria through feces.
\end{abstract}

Keywords: Salmonellosis, Salmonella entrica serovar Albany, Pathogenesis

DOI: 10.33899/ijvs.2019.126269.1282, (02020, College of Veterinary Medicine, University of Mosul.

This is an open access article under the CC BY 4.0 license (http://creativecommons.org/licenses/by/4.0/).

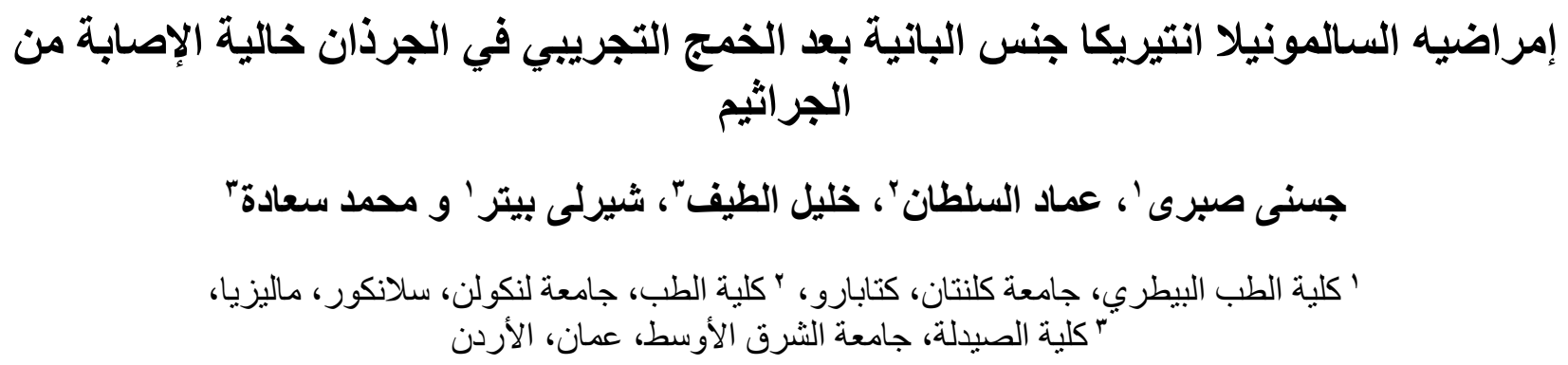

الخلاصة

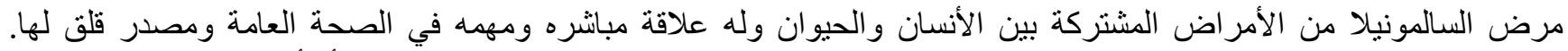

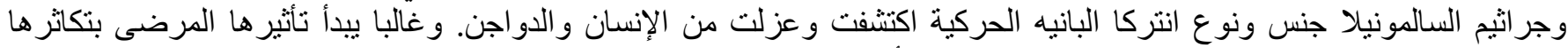

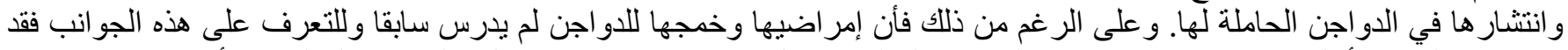

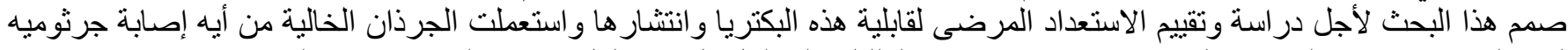

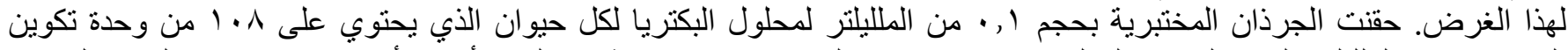

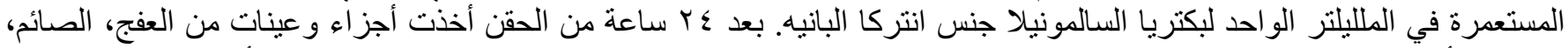
الدقاق، الأعور و القولون وضعت في مثبت لدر اسة التغيرات النسيجية وكذللك فحص البوليمير التفاعلي المنسلسل لتأكيد وجود السالمونيلا 


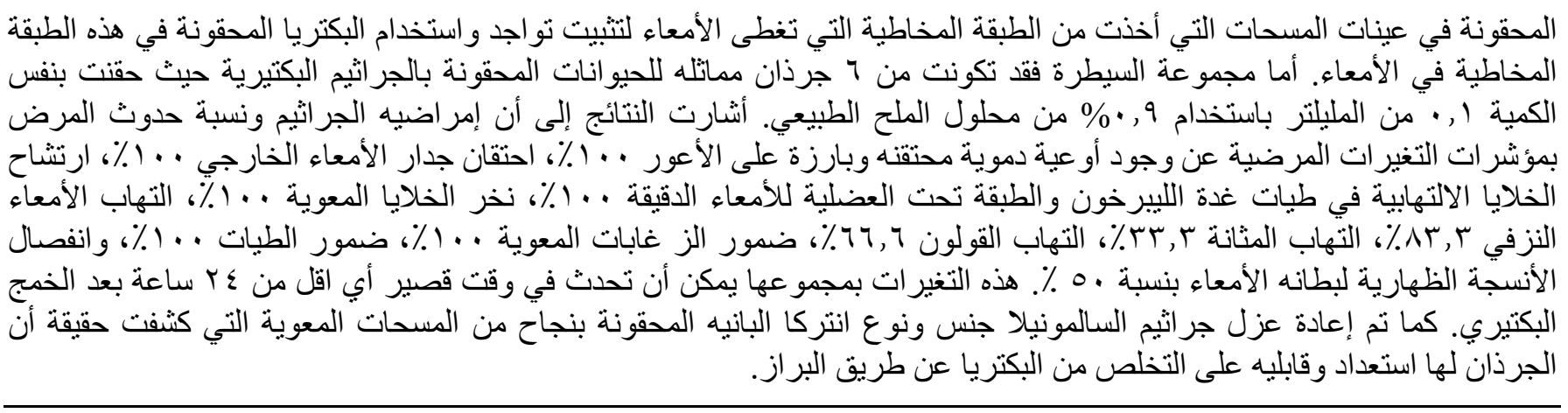

\section{Introduction}

Salmonella spp. are Gram-negative, facultative intracellular bacteria and has a worldwide distribution $(1,2)$. Romania reported two Salmonella serovars in poultry that affect humans, namely $S$. enteritidis and $S$. typhimurium, and other non-typhoid strains including S. infantis, S. derby, $S$. colindale, $S$. rissen, $S$. ruzizi, $S$. virchow, S. brandenburg, $S$. bredeney, S. muenchen, S. kortrijk, and $S$. calabar $(3,4)$. Salmonella enterica is one of the common causes of gastroenteritis and bacteraemia in humans. S. enterica is present in a wide range of animals, particularly food animals and have been identified as reservoirs for non-typhi Salmonella (5). However, Salmonella are very persistent which can survive at least 26 months in artificially contaminated poultry food (6). Salmonellosis remains an important zoonotic disease and public health concern. The disease is known to be most prevalent in areas of intensive animal husbandry, especially in swine, poultry, and cattle as well as in animal products such as poultry eggs, milk and fresh seafood $(7,8)$. Infection with Salmonella often causes gastroenteritis with increase susceptibility in young children, older people and immunosuppressed person $(6,9)$.

Raw chicken products are an important part of international food trade. In poultry, the infection of Salmonella often infects a flock and is carried asymptomatically in the gastrointestinal tract of a proportion of the birds and subsequently may be transferred to carcasses during processing via fecal contamination (7). Furthermore, contamination of the carcasses, assist the transmission of the Salmonella to human which cause foodborne disease. Vast majority of foodborne cases are undiagnosed, however in the United States it has been estimated that foodborne diseases cause approximately 76 million illness with 325000 hospitalization and 5000 deaths each year. Consumption of contaminated poultry meat with Salmonella will contribute to the elevation of foodborne cases since poultry meat consumption is the highest record per capita meat consumption $(10,11)$. According to the data documented by Laboratory Based Surveillance, Disease Control Division, Ministry of Health Malaysia, S.enterica serovar Albany was listed in top 10 non-typhoidal
Salmonella serotypes identified in year 2003, 2004 and 2005 (12).

Recent study, there has been isolation of S.enterica serovar Albany from poultry meat samples which is collected from wet markets Pengkalan Chepa with antimicrobial sensitivity test show resistance towards Streptomycin and Tetracycline. Pathology and pathogenesis of $S$. Typhimurium in mouse model discovered in vivo intestinal disease or enterocolitis $(5,13,14)$. While study of enteritis and typhoid fever using mouse models of Salmonella infection specifically on serotype Typhi was also done but for serotype Albany experimental infection study using animal models is still lack $(15,16)$. Therefore study of pathology and pathogenesis on the disease caused by this pathogen is quite significant due to the fact that this bacterium can be potentially zoonotic.

\section{Materials and methods}

\section{Preparation of bacteria inoculum}

Salmonella enterica serovar Albany was used throughout this study. This bacteria culture was isolated from chicken carcasses obtained from a wet market. The culture is kept in nutrient agar slant at room temperature and was propagated on nutrient agar plate before used. Bacterial culture was diluted in sterile saline solution by using McFarland standard 0.5 to make $10^{8} \mathrm{CFU} / \mathrm{ml}$.

\section{Experimental animals}

Twelve SPF BALB/c mice between 12 weeks of age were used in this experiment. The mice that were purchased from University Sains Malaysia Laboratory Kubang Kerian, Kota Bharu, Kelantan were healthy and free from pathogen infection was housed under specific pathogen free (SPF) condition that are free of specified micro-organisms and parasites, but not necessarily free of others not specified and also their SPF BALB/c mice lacked facultatively anaerobic gram-negative bacteria, such as Escherichia coli, in their gut microbiota. Three mice were kept per cage at the laboratory animal room at the Faculty of Veterinary Medicine, University Malaysia Kelantan. 


\section{Animal infection}

The animals were divided into two groups which is the control group and experimental groups. Control group consists of 6 mice and experimental group consist of 6 mice. Both groups were given ad-libitum of commercial mice pallet and water. Animal infection was carried out by inoculating mice per orally using modified gavage needle by using indwelling catheter size 18 gauge.

The control group (Group A) was inoculated with $0.1 \mathrm{ml}$ of $0.9 \%$ normal saline, while experiment group (Group B) was inoculated with $0.1 \mathrm{ml}$ volume for each mice bacterial solution of $10^{8} \mathrm{CFU} / \mathrm{ml}$ of bacteria. Water and food were removed 4 hours prior to the experimental infection. Then, drinking water was provided immediately after infection and food was provided 2 hours post-infection. The infected mice was examined twice daily for any clinical signs and mortality. Two mice were euthanized every day from the experiment group and two mouse euthanized from Control group on post inoculation. Then, post-mortem was performed immediately after euthanization and the organ samples such as the small intestine (duodenum, jejunum and ileum), caecum and colon were collected and the gross lesions were observed and recorded.

\section{Bacteriology}

Intestinal mucosal swabs were collected using sterile cotton swab from small intestine, caecum and colon. The swabs were immediately placed in $20 \mathrm{ml}$ of sterile buffered peptone water (BPW) at $\mathrm{pH} 7.0$ and incubated at $37^{\circ} \mathrm{C}$ for 48 hours. $1 \mathrm{ml}$ of the solution was transferred into $10 \mathrm{ml}$ of tetrathionate broth (TTB) and incubated at $42^{\circ} \mathrm{C}$ for 24 hours before isolation. The sample spread onto selective media. Suspected Salmonella spp. colonies were taken for biochemical test. Polymerase chain reaction (PCR) was used to confirm the Salmonella spp.

\section{DNA extraction}

For extracting DNA from an isolate, the preserved isolate was inoculated onto $5 \%$ citrated bovine blood agar at first which was then incubated for 24 hours at $37^{\circ} \mathrm{C}$. Three to four colonies from the agar plate were transferred to a $1.5 \mathrm{ml}$ Eppendorf tube containing $200 \mu \mathrm{l}$ de-ionized water and mixed well. The tube was vortexed and heated at $99{ }^{\circ} \mathrm{C}$ for 15 minutes and immediately transferred onto ice. The suspension was then centrifuged at $15000 \mathrm{rpm}$ for 2 minutes. After centrifuge, $100 \mu \mathrm{l}$ of the supernatant was transferred into a new Eppendorf tube which was used as DNA template.

\section{Polymerase Chain Reaction}

The sequences of specific gene (invA) of the primer set used to detect S.enterica serovar Albany were (F) 5'-AGC CAA CCA TTG CTAA AT TG -3' and (R) 5'-GGT AGA AAT TCC CAG CGG GTA CTG-3' published elsewhere for the identification of Salmonella. PCR was performed by using a PCR mastermix (Vivantis Technologies Sdn. Bhd.) and was prepares in a final volume of $25 \mu \mathrm{L}$ containing 0.5 pmol of each primer, $9.5 \mu \mathrm{L}$ nucleus free water, $12.5 \mu \mathrm{L}$ of mastermix solution and $2 \mu \mathrm{l}$ of DNA extract. the mixture then subjected to 35 cycles of amplification in a thermal cycler (Table 1). The PCR product were analysed on $1.5 \%$ $(\mathrm{w} / \mathrm{v})$ agarose gel electrophoresis at 100 volt for 30 minutes for 8 wells agarose gel and at 85 volt for 45 minutes for 20 wells agarose gel (Figure 1).

Table 1: PCR cycling protocol

\begin{tabular}{lc}
\hline Steps & Target gene \\
\hline Initial denaturation & $94{ }^{\circ} \mathrm{C}$ at $3 \mathrm{~min}$ \\
Denaturation & $94{ }^{\circ} \mathrm{C}$ at $30 \mathrm{sec}$ \\
Annealing & $50{ }^{\circ} \mathrm{C}$ at $30 \mathrm{sec}$ \\
Extension & $72{ }^{\circ} \mathrm{C}$ at $30 \mathrm{sec}$ \\
Final extension & $72{ }^{\circ} \mathrm{C}$ at $3 \mathrm{~min}$ \\
Hold & $4{ }^{\circ} \mathrm{C}$ \\
\hline
\end{tabular}

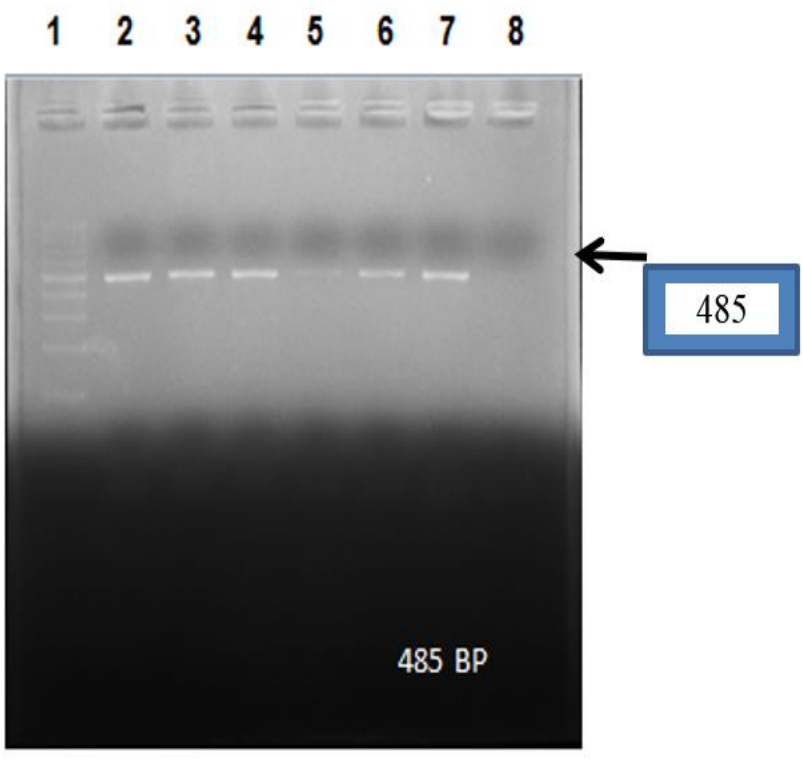

Figure 1: PCR result from re-isolation of $S$. enterica serovar Albany from experimental mouse. Lane 1 is a ladder, lane 2 is positive control, lane 3 to lane 7 is samples from small intestines swab from 6 of the experimental mouse and lane 8 is negative control.

\section{Histopathology}

Segments of the duodenum, jejunum, ileum, caecum and colon were fixed in $10 \%$ buffered formalin for 48 hours. After 48 hours, the samples were sectioned, stained with hematoxylin and eosin (H\&E) stains. The sections were observed for microscopic changes using a light microscope (Table 2). 
Table 2: Standard tissue processing protocol of Leica ${ }^{\circledR}$

\begin{tabular}{lcc}
\hline Station & Reagent & Time \\
\hline 1 & Formalin & $1 \mathrm{~h} 00$ \\
2 & Formalin & $1 \mathrm{~h} 00$ \\
3 & Alcohol 70\% & $1 \mathrm{~h} 30$ \\
4 & Alcohol 80\% & $1 \mathrm{~h} 30$ \\
5 & Alcohol 96\% & $1 \mathrm{~h} 30$ \\
6 & Alcohol 100\% & $1 \mathrm{~h} 00$ \\
7 & Alcohol 100\% & $1 \mathrm{~h} 00$ \\
8 & Alcohol 100\% & $1 \mathrm{~h} 00$ \\
9 & Xylene & $1 \mathrm{~h} 30$ \\
10 & Xylene & $1 \mathrm{~h} 30$ \\
11 & Paraffin & $2 \mathrm{~h} 00$ \\
12 & Paraffin & $2 \mathrm{~h} 00$ \\
\hline
\end{tabular}

\section{Results}

\section{Post Infection Clinical Signs}

Mice inoculated with $10^{8} \mathrm{CFU} / \mathrm{ml}$ of bacteria per orally with S.enterica serovar Albany did not cause diarrhea, However, it causes depression between two to four hours post-infection. There was no death occur in this experiment, all mice were euthanized to proceed pathological examination.

\section{Bacterial isolation}

All suspected colonies from all samples of experimental mouse show urease reaction negative, $\mathrm{H}_{2} \mathrm{~S}$ positive (TSI), motility test (SIM) positive, oxidase test negative, indole negative, Methyl Red positive, and Simmons citrate positive. All isolates were further identified by PCR confirmation. All samples from the control mouse show no growth of suspected Salmonella spp. colonies on XLD agar.

\section{PCR Confirmation}

Eighteen samples from small intestine, caecum and colon swabs from the experimental mouse show positive for S.enterica serovar Albany. The results for gross lesion, histopathology and morphological diagnosis as in table 3.

Gross lesion of the small intestine of the control mice and gross lesion of small intestine of the experimental mice after 3 days post infection. Mesenteric blood vessels of the experimental mice are congested and serosal layer are reddened. Control mice absence of mesenteric blood vessels congestion and absence of serosal layer reddening; Figure 2.

Grossly, there is no evidence of ulceration on the intestinal mucosal layer. S.enterica serovar Albany colonizes along the small, caecum and colon, S.enterica serovar Albany was re-isolated from all part of the intestines and confirmed by PCR. Therefore, pathological changes are able to be seen in all part of the intestines. Experimental infection of S.enterica serovar Albany revealed that this bacteria cause enteritis, cecitis and colonitis. The inflammations are predominantly by macrophages. Haemorrhages and epithelial layer erosion are seen in small intestine; Figure 3. Inflammations at the colon are predominantly also by macrophages; Figure 4 and histopathological analysis of the colon post-infection; Figure 5.

Table 3: Gross and histopathology lesion summary after 1 day post-infection

\begin{tabular}{lc}
\hline Histopathology lesion & $\%$ \\
\hline Prominent blood vessels on caecum & $6 / 6(100 \%)$ \\
Red intestinal serosal & $6 / 6(100 \%)$ \\
Infiltration of inflammatory cells & $6 / 6(100 \%)$ \\
in the crypt of liberkhun & \\
Infiltration of inflammatory cells in the & $6 / 6(100 \%)$ \\
submuscular layer of small intestine & $6 / 6(100 \%)$ \\
Enterocyte necrosis & $5 / 6(83.3 \%)$ \\
Haemorhagic enteritis & $4 / 6(66.6 \%)$ \\
Cecitis & $2 / 6(33.3 \%)$ \\
Haemorrhagic cecitis & $4 / 6(66.6 \%)$ \\
Colonitis & $2 / 6(33.3 \%)$ \\
Haemorrhagic colonitis & $6 / 6(100 \%)$ \\
Villus atrophy & $6 / 6(100 \%)$ \\
Crypt atrophy & $3 / 6(50 \%)$ \\
Detachment of epithelial tissue &
\end{tabular}

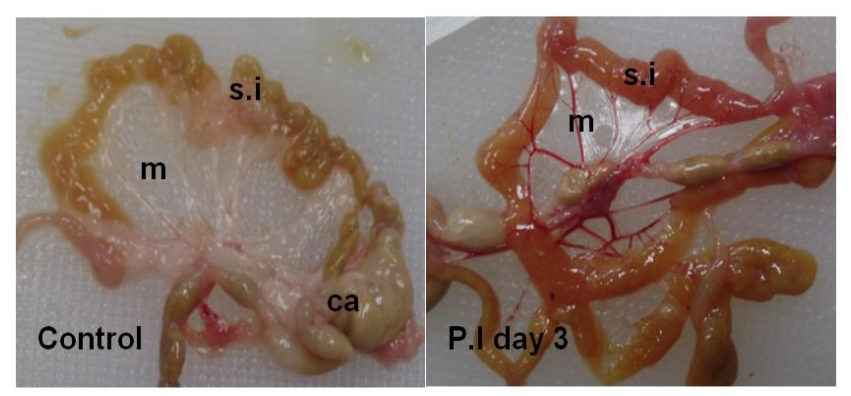

Figure 2: Gross lesion of the small intestine after 3 days post infection. Mesenteric blood vessels of the experimental mice are congested and serosal layer are reddened. Control mice absence of mesenteric blood vessels congestion and absence of serosal layer reddening. Abbreviation; m: mesenteric blood vessels, s.i: small intestine, ca: caecum, p.i: post infection.

\section{Discussion}

Many studies suggested that poultry, especially chicken could be the most common reservoir of Salmonella spp. (17) and it's a hallmark of Salmonella enteritis in human diarrhoea $(17,18)$. Result from this study reveals that experimental infection of S.enterica serovar Albany in mice do cause lesion such as enteritis, cecitis and colonitis right after 24 hours post infection. S.enterica serovar 
Albany is a serovar rarely isolated from infectious processes (13).

However in Malaysia it is listed top in top 10 nontyphoidal Salmonella serotypes identified in year 2003, 2004 and 2005 stated by Laboratory Based Surveillance, Disease Control Division, Ministry of Health Malaysia.
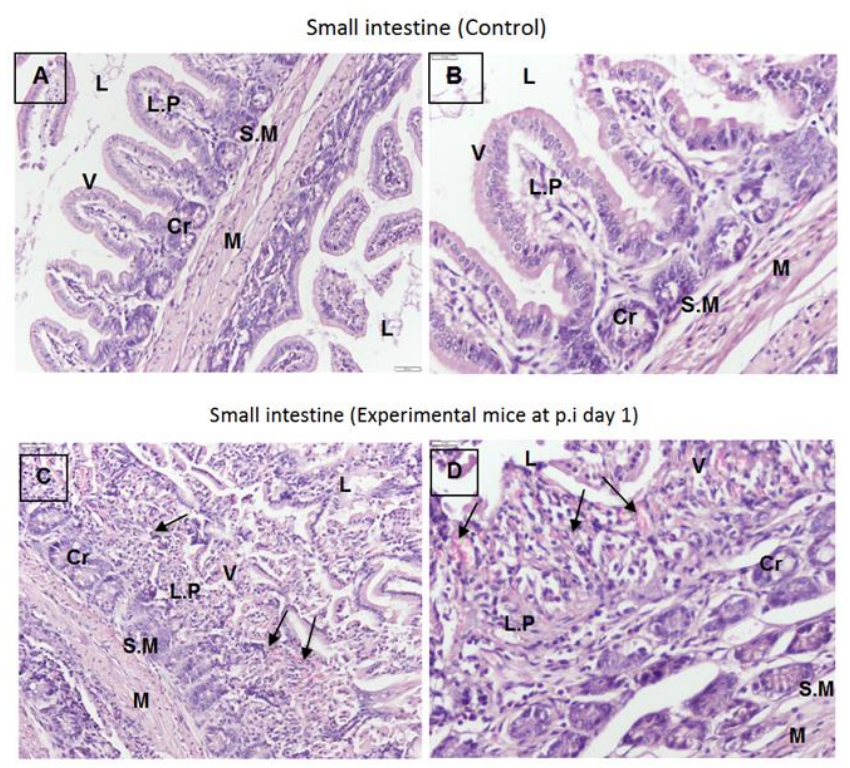

Figure 3: Histopathological analysis of the small intestine after 1 day post-infection. A and B are section of the small intestine from control mice stained with H\&E. C and D are section of the small intestine from experimental mice at after 1 day post-infection stained with $\mathrm{H} \& \mathrm{E}$. Arrows in $\mathrm{C}$ and $\mathrm{D}$ shows the haemorrhages on the small intestines. $\mathrm{C}$ and $\mathrm{D}$ show the erosion of the epithelial cells and also disruption of the villus. In $\mathrm{C}$ and $\mathrm{D}$ there are also infiltrations of the inflammatory cells in the lamina propria predominantly by macrophages and also infiltrated with PMN. Abbreviation; L: lumen, Cr: crypt of Liberkhun, v: villus, S.M: submucosa, M: muscular layer, L.P: lamina propria.

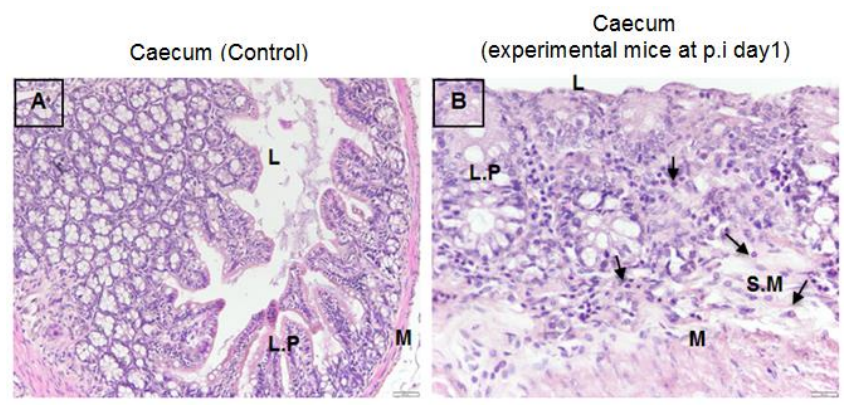

Figure 4: Histopathological analysis of the caecum after 1 day post-infection. A is a section of caecum from the control mice stained with $\mathrm{H} \& \mathrm{E}$. B is a section of caecum from the experimental mice at p.i day 1 stained with $H \& E$. Arrows in B shows the infiltrations of the inflammatory cells in the lamina propria and submuscular layer, predominantly by neutrophils. In $\mathrm{B}$, loss of the crypt architecture and enterocyte necrosis. Abbreviation; L: lumen, S.M: submucosa, M: muscular layer, L.P: lamina propria.

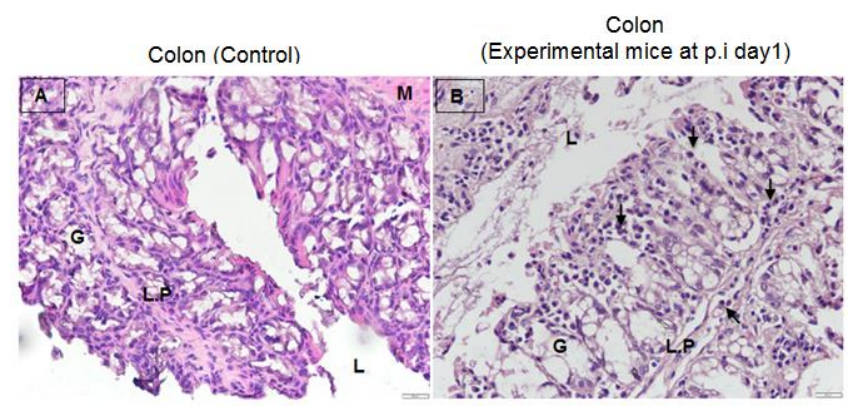

Figure 5: Histopathological analysis of the colon after 1 day post-infection. A is a section of colon from the Control mice treated with $0.1 \mathrm{ml}$ of $0.9 \%$ normal saline, stained with H\&E. B is a section of colon from the experimental mice at p.i day 1 of $0.1 \mathrm{ml}, 10^{8} \mathrm{CFU} / \mathrm{ml}$ of S.enterica serovar Albany stained with H\&E. Arrows in B shows the infiltrations of the inflammatory cells in the lamina propria and submuscular layer, predominantly by macrophages. B, necrosis of the crypt and vacoulation of the goblet cells. Abbreviation; L: lumen, S.M: submucosa, M: muscular layer, L.P: lamina propria, G: goblet cell.

Oral ingestion of S.enterica serovar Albany form undercooked poultry meat cause salmonellosis. Findings such as enteritis, cecitis and colonitis in this study resemble the findings in human salmonellosis.

Results from similar study revealed that oral infection of S.enterica serovar Albany do not cause diarrhea in mice unlike in human (19).

However, a previous study-found that feeding of chicken contaminated with S.enterica serovar Albany to ocelot in captivity cause salmonellosis and necropsy of the ocelot revealed ileum, villi and crypt necrosis as well as severe mononuclear lymphocytic infiltration $(20,21)$.

Mice villus necrosis resemble the finding in the study of ocelot, however in this inflammatory cells infiltration is different from previous finding.

Macrophages were found to be predominant inflammatory reaction in this study. Bacteria re-isolation is $100 \%$ re-isolated from all experimental mouse's small intestine, caecum and colon swabs. This finding is resemble the finding form the study in ocelot that feed with contaminated chicken meat with S.enterica serovar Albany, where Salmonella serotype isolated from the feed sample is same as Salmonella serotype isolated from the ocelot feces $(17,20)$. 
As S.enterica serovar Albany was isolated from all part of the intestines, it reveals that mice do shed Salmonella spp. through their feces asymptomatically.

\section{Conclusion}

The pathogenesis of the disease caused by S.enterica serovar Albany revealed that haemorrhagic enteritis, cecitis and colonitis can occur as soon as 24 hours post infection. Infected bacteria sp. also was successfully re-isolated from the intestinal swabs which revealed that the mice is potentially shed the bacteria through feces.

\section{Acknowledgement}

The authors are grateful to the Middle East University, Amman, Jordan for the financial support granted to cover the publication of this article.

\section{Conflict of interest}

None

\section{Ethical clearance}

All animal experiments were performed in accordance with the guidelines of the National Council for Animal Experimentation Control (CONCEA) and the Ethical Committee approval was obtained from ethical committee of University Malaysia Kelantan-Malaysia.

\section{References}

1. Wickham ME, Brown N F, Provias J, Finlay BB, Coombes BK. Oral infection of mice with Salmonella enterica serovar typhimurium causes meningitis and infection of the brain. BMC Infect Dis. 2007;7:65. https://doi.org/10.1186/1471-2334-7-65

2. Alexander DP, James MS. Mechanisms of Salmonella pathogenesis in animal models. Hum Ecol Risk Assess. 2017;23(8):1877-1892. https://doi.org/10.1080/10807039.2017.1353903

3. Barbour EK, Ayyash DB, Alturkistni W, Alyahiby A, Yaghmoor S, Iyer A, Yousef J, Kumosani $T$, Harakeh S. Impact of sporadic reporting of poultry Salmonella serovars from selected developing countries. J Infect Devel Countries. 2015;9:1. https://doi:10.3855/jidc.5065

4. Gupta SK, Sharma P, McMillan EA, Jackson CR, Hiott LM, Woodley T, Humayoun SB, Barrett JB, Frye JG, McClelland M. Genomic comparison of diverse Salmonella serovars isolated from swine. PLoS One. 2019;14:11. https://doi.org/10.1371/journal. pone.0224518

5. Hendriksen RS, Bangtrakulnonth A, Pulsrikarn C, Pornreongwong S, Hasman H, Song SW, Aarestrup FM. Antimicrobial resistance and molecular epidemiology of Salmonella rissen from animals, food products, and patients in Thailand and Denmark. Foodborne Path Dis. 2008;5(5):605-619. https://doi.org/10.1089/fpd.2007.0075
6. Meerburg BG, Kijlstra A. Role of rodents in transmission of Salmonella and Campylobacter. J Sci Food Agri. 2007;87:15. https://doi.org/10.1002/jsfa.3004

7. Valdezate S, Vidal A, Herrera LS, Pozo J, Rubio P, Usera MA, Echeita MA. Salmonella Derby Clonal Spread from Pork. J Vet Res. 2005;11(5):694-698. https:// doi: 10.3201/eid1105.041042

8. Kelly MJ, Simpson GA, Hill C, Michael P, Ward SM. Diversity of Salmonella serotypes from humans, food, domestic animals and wildlife in New South Wales, Australia. BMC Infect Dis. 2018;18:623. https://doi.org/10.1186/s12879-018-3563-1

9. Mead G, Lammerding AM, Cox N, Doyle MP, Humbert F, Kulikovskiy A, Wierup M. Scientific and technical factors affecting the setting of Salmonella criteria for raw poultry: A global $\begin{array}{llll}\text { perspective. J Food Protect. 2010;73(8):1566-1590. } & \text { J }\end{array}$ https://doi.org/10.4315/0362-028X-73.8.1566

10. Modarressi S, Thong KL. Isolation and molecular sub typing of Salmonella enterica from chicken, beef and street foods in Malaysia. BMC Infect dis. 2010;5(18):2713-2720. http://eprints.um.edu.my/id/eprint/5572

11. Soon JM, Singh H, Baines R. Foodborne diseases in Malaysia: A $\begin{array}{llll}\text { review. Food } & \text { Control. }\end{array}$ https://doi.org/10.1016/j.foodcont.2010.12.011

12. Boyen F, Haesebrouck F, Maes D, Van Immerseel F, Ducatelle R, Pasmans F. Non typhoidal Salmonella infections in pigs: a closer look at epidemiology, pathogenesis and control. Vet Microbiol. 2008;27;130(1-2):1-19. https://doi.org/10.1016/j.vetmic.2007.12.017

13. Hapfelmeier S, Hardt WD. A mouse model for S. typhimuriuminduced enterocolitis. Trends Microbiol. 2005;13(10):497-503. https://doi.org/10.1016/j.tim.2005.08.008

14. Mathur R,Oh H, Zhang D, Sung SG,Seo J, Koblansky A, Hayden MS, Ghosh S. A mouse model of Salmonella typhi infection. Cell. 2012;151(3):590-602. https://doi.org/10.1016/j.cell.2012.08.042

15. Elena V, Gart Jan S, Suchodolski TH, Welsh Jr, Robert C, Alaniz RD, Randel SD. Salmonella typhimurium and Multidirectional Communication in the Gut. Front Microbiol. 2016;7:1827. https://doi.org/10.3389/fmicb.2016.01827

16. Santos RL, Zhang S, Tsolis RM, Kingsley RA, Garry Adams L, Bäumler AJ. Animal models of Salmonella infections: Enteritis versus typhoid fever. Microb Infect. 2001;3(14-15):1335-1344. https://doi.org/10.1016/S1286-4579(01)01495-2

17. Foley SL, Nayak R, Hanning IB, Johnson TJ, Han J, Ricke SC. Population Dynamics of Salmonella enterica Serotypes in commercial egg and poultry production. Appl Environ Microbiol. 2011;77(13):4273-4279. doi: 10.1128/AEM.00598-11

18. Chen MH, Wang SW, Hwang WZ, Tsai SJ, Hsih YC, Chiou CS, Tsen HY. Contamination of Salmonella Schwarzengrund cells in chicken meat from traditional marketplaces in Taiwan and comparison of their antibiograms with those of the human isolates. Poult Sci. 2010;89(2):359-365. https://doi.org/10.3382/ps.2009-00001

19. Fierer J, Okamoto S, Banerjee A, Guineya DG. Diarrhea and colitis in mice require the Salmonella pathogenicity island 2-encoded secretion function but not SifA or Spv effectors. Infect Immunit. 2012;80(10):3360-3370. doi: 10.1128/IAI.00404-12

20. Silva HG. Fecal excretion of Salmonella albany, its isolation in the diet and health repercussion on an ocelot (Leopardus pardalis) in captivity. Notas de Investigación. 2012;1(1):59-69.

21. Saleh ZF, Al-Muhana BM, Hamdan Kh, Jawad MS, Klaif SF. Isolation and identification of Salmonella typhimurium bacteria with detection of type-1 fimbriae coding gene by polymerase chain reaction (PCR) technique. Iraqi J. Vet. Sci. 2019;33(1):195-199. doi: 10.33899/ijvs.2019.162961 